\title{
TECHNOLOGY-ENHANCED ENGLISH LANGUAGE LEARNING AND TEACHING
}

CSultanova D., ORCID: 0000-0002-5820-7173, Tashkent State University of Economics, Tashkent,Uzbekistan,sultanova_dilfuz@mail.ru

CMaksudova D., Tashkent State University of Economics, Tashkent, Uzbekistan

\section{ОБУЧЕНИЕ АНГЛИЙСКОМУ ЯЗЫКУ С ИСПОЛЬЗОВАНИЕМ НОВЫХ ТЕХНОЛОГИЙ}

\begin{abstract}
ССултанова Д. T., ORCID: 0000-0002-5820-7173, Ташкентский государственный экономический университет, г. Ташкент, Узбекистан, sultanova_dilfuz@mail.ru СМаксудова Д. К., Ташкентский государственный экономический университет, 2. Ташкент, Узбекистан
\end{abstract}

Abstract. The article deals with information and communication technologies as methods of increasing of study activity of students in the process of learning English language. Implementation of information and communication technologies in study process leads to improvement of academic effectiveness, increase of student's interest in self-knowledge, their motivation and comfort in the study process. It also helps to build-up students self-work.

Аннотация. Рассмотрены информационные и коммуникационные технологии как наилучшие способы применения для интенсификации и повышения учебной активности студентов в изучении английского языка. Внедрение информационных и коммуникационных технологий в учебный процесс приводит к возрастанию эффективности обучения, повышает интерес студентов к самопознанию, мотивацию изучения языка, комфортность в учебном процессе и способствует повышению уровня сформированности навыков самостоятельной работы студентов.

Keywords: multimedia, self-education, internet, information and communication technology, language learning, learning environment, technology-supported learning activities, professional development, self-knowledge.

Ключевые слова: мультимедиа, самообразование, интернет, информационные и коммуникационные технологии, обучение языку, профессиональное развитие, технология обучения, учебная среда, самообразование.

\section{Main part}

Teaching using innovation technology is necessarily in the 21 century. We will say that the technology can be exercised unsuitably in schools and can be_destructive for the young generation and for also for the students that are leaving behind the classic models of learning and practice new tools. The answer is that the technologies have given mankind unlimited entrance to information which can be turned into knowledge. Suitably used-interactively arid with direction the innovation technologies and the information have become methods for the growth of higher instruction thinking capabilities (https://clck.ru/FMNhu). 
The process of teaching a second language may be considered in various ways - in an educational institute or at home, with or without an instructor, giving special importance or belittle grammar, gradually exposing the student to native speakers or fast dipping. No matter where and how the teaching happens, information and communication technologies are useful innovation to improve the teaching process.

Communication and information technology is developing gradually at remarkable rate. It has fundamentally changed the methods we teach and spend our free time. Computers and information technologies have obviously revolutionized nearly every phase of our life - how and where we listen to news, how we buy goods and services, and how we take a deal. It is both suitable and prospective that technology should also provide the way to enhance teaching and learning in our educational institutions.

Communication and information technology should be an instrument to allow educators are up to the educational requirements of all students. As such, technologies cannot function as fulfillment in isolation but must be thought of as main parts in making it possible for universities and institutions to address core educational challenges [1].

However, technology and equity are not unavoidable partners. Simply providing way does not ensure that technology will usefully develop teaching and learning and result in improved results. Nor does providing way imply that all teachers and students will make effective use of the technology.

Language teachers should improve their capabilities with training on the use of technology, including multimedia, computers, and smart boards in the classroom. Viewed in conditions of teaching, many recommend that teachers should have fundamental technology art and be able to:

-Use technology for individual productivity.

-Use technology to allow learning in a subject area.

-Adapt technology-supported learning tools.

-Provide student-centered, technology-supported activities.

-Develop student capabilities within the frame work of technology-supported activities [2]

Communication and information technology provides new methods of teaching and learning, and offers new ways for all involved in education to be openly liable to teachers and students. Technology is a main part of our educational process, and it is a difficult task to understand the effective role of technology from the effects of other factors that influence teaching and learning English language.

Communication and information technology is a way of changing education, as online teaching allows students to get degrees through only online courses. Online classes can use Computer-Based Trainings in place of lectures. Computer-Based Trainings are self-paced activities on a computer that present content to students. The trainings often include assessments that can be fast scored, providing feedback to the students. The courses offer media such as videos and pictures to be used in connection with text. Online sources are also developing online collaboration instruments to attract students to learn jointly online.

New communication and information technologies and methods of learning could greatly change education of the future. The Internet provides people to choose through digital information and join students to experts. Textbooks can become interactive and can easily include innovations and corrections. Students will likely be able to find coursework from whichever university they choose, and courses will likely be jointly. These updates will provide universities to teach anyone wishing to study, rather than only a choose few in a classroom [3]. 
In the future, we can hope that new information and communication technologies will appear, and they will be increasingly suitable for educational aims. As technology updates, the way we learn will change, and educational systems will be forced to change to adjust students' learning tools. Students will get useful information from various technologies. It's up to the educational system to understand that students are turning to technologies for education, and to teach students how to use the information they get through technology.

Students are exercising the computers and many useful supplements to study, use and practice the gained acknowledgements and these new instruments are not so different from textbooks. Teachers can use innovation technology to prepare more vivid, attractive lectures. To sum up, that technology is used usefully to create new possibilities for learning and to provide students good results.

Social networking sites promote students to develop their interests on a wide scale and share their interests with many people. This has large implications for self-learning, as information and resources are much more acceptable than they were previously. However, for students that aren't experienced at evaluating different content, it can be difficult for them to select through different resources to choose useful information. Through all of these technological updates, students today learn in much various ways than students of the past.

Students hope that they can learn about anything they want almost immediately. While this is often true, it's difficult for subjects that require more in-depth research or extended thinking.

The Internet promotes student's knowledge obtaining by developing students' access to resources from the outside world including experts in the field, as well as interacting directly with them. Thus exposure to real life contexts of the external world trains the students to face theuncertainties of the ever-changing outside world. In providing instruments for communication, the Internet is a useful tool for fast communication. Such cooperation provides communication with students and experts in distant places, cultures and traditions as well as expert teachers to be intouch with other teachers.

The use of communication and information technology cannot be undervalued in language teaching and learning process because emerging technologies make it relevant and practical to fit learning in ways that have been recognized by scientists, educational psychologists. It is significant for modern day teachers and learners to keep abreast of the modern tools at improving teaching and learning of English Language through the use of communication and information Technology. Suffice it to say that information and communication technology has changed society globally, including how language instruction is taught and delivered.

It is important to emphasize that communication and information technology does not just mean computers - it covers a wide range of learning technologies found in educational institutions, from digital cameras to interactive whiteboards. Information and communication technology resources are often expensive and we will need to understand how much any new equipment will actually use to positive learning. For example, programmes and resources should meet criteria such as the following:

- promote students to be in control and encourages independent thought rather than 'leading' them to a specific conclusion;

-allow students' interests, for example in English;

- promote students to be creative and exercise their own ideas;

- are not aggressive;

-avoid stereotyping [4] 
Uzbekistan's society always sees its future in an educated, healthy and harmonically developed generation. For the years of independence education sector has been brought into the foreground of development and modernization of the country; its full reformation has become a priority direction of the government policy. By the present the republic has created modern conditions not only for successful education on all the phases of education, but also for effective work of teachers. The authority of the mentor, prestige of teacher's profession are high now, and criteria of worthy assessment and reward of teacher's work has become professionalism, loyalty to upbringing and education matter, creativity and innovation.

The decree of the First President of the Republic of Uzbekistan Islam Karimov "On measures for further improvement of foreign language learning" from December 10, 2012 is an important factor in improving teaching of foreign languages to a new level. Extensive works on the continuous learning of foreign languages at all stages of the education system, professional development of teachers to provide educational institutions with modern teaching materials are conducted for effective implementation of the tasks, set out in the document.

In this direction effective measures to improve access of educational institutions to sources of international education through «ZiyoNet» public information and education network, fill the network with multimedia resources, update applications for personal computers and mobile gadgets. Introducing new technologies for fast, easy and independent student learning experience has become the demand of time. Consequently, teaching materials on English language on the «ZiyoNet» public information and education network play an important role in self-improvement of teachers, enriching their knowledge and skills.

Getting education in such a friendly atmosphere, the students obtain skills and knowledge, allowing them to become competitive specialists in fast-changing world, market conditions. New requirements to teachers introduced new technology to have its rigid place in study process. Having come to the aid, it required corresponding skills of teachers, education of corresponding specialists, possessing knowledge on information communication technology.

The ways that technologies are being used in educational institutions change the teacher's role from that of technology-as-teacher to technology-as-partner in the learning process. As students increasingly use technologies as learning tools, they will produce technology-based artifacts student-constructed knowledge bases. These knowledge bases are rich, multi-modal indicators of what students have learned. Moreover, as learning becomes more meaningful, so it becomes more authentic and more complex [5].

Unfortunately, not too many teachers have acquired the competencies to conduct authentic assessments for student learning, using learning portfolios and rubrics for performance evaluation. The need for such learning assessment competency becomes even more urgent as educators move away from the behaviourist and objectivist perspective of learning to that of a more constructivist view [6]

Language teachers should update their skills with training on the use of technology, including computers, multimedia, and smart boards in the language-learning classroom. Changed educational institutions, modernized educational process changed the treatment of study of students, teachers say. Students are striving to get more knowledge, realizing the fact that mental furniture got for the years of study is the basis of their future. Along with that, the changes that came with the issues brought in another important requirement to teachers, which is self-improvement. Experts say it is one of the main demands of the modern world, where there is more and more information day by day $[7-10]$. 


\section{Conclusion}

To our mind, we enjoy and value all the benefits of education on-demand. We hope the future was here already because deep down inside, we all are lifelong learners. We just want learning to be easy. This vision is inviting, yet we must live and work in present time. And today, the reality stays apart from the dream. The challenge to educators is clear. We must also improve standards of quality in the products, services, and solutions we suggest to the younger generation. We have to learn how to prepare all of our students for lives that are becoming more and more complex. We have to prepare our students to master change.

Communication and information technology is become more and more popular in English teaching. It is one of the best tools to motivate vocational students' interests in their English learning. It also promotes English teachers flexibly to present their curriculum in up-to-date manner.

Communication and information is a form of advanced science technology must be developed function, especially in the fulfillment of learning. This technology provides facilities for students in the era of global competition needs to obtain adequate supplies. Through innovative technology based learning can promote vivid possibilities for students to develop their competence on an international scale. On the other hand, mental attitude and self-reliance in accessing any information necessary learning independently influence the value teaching student's approach it does not always depends with others. Mastering current tick is necessity for every human being inedible age as well as in education, up to date learning, especially learning can be done by using the Internet to develop device-based learning information and communication technology.

The aim of the new information and communication technologies used in learning and teaching process is that each country of the world can access professional learning systems and make educational institutes' development plans and strategies. There may be expectations that technology will tackle all the university's problems with student learning and achievement. To be effective, however, technology have to be used to allow new learning aims and teaching strategies that are student-centered, collaborative, self-motivated, and based on development of higher-order thinking skills.

Finally, it may be concluded, the communication and information technology used in learning and teaching process represents the future of our humanity, and the purpose is to develop a knowledge based society.

\section{References:}

1. Bajcsy, R. (2009). Technology and learning. In Visions 2020: Transforming education and training through advanced technologies. Washington, DC: U.S. Department of Commerce.

2. Bennett, D., Culp, K. M., Honey, M., Tally, B., \& Spielvogel, B. (2008). It all depends: Strategies for designing technologies for educational change. Paper presented at the International Conference on Learning Technology, Philadelphia, PA.

3. Davies, G. (2011). Introduction to multimedia CALL. Module 2.2 in Davies G. (ed.) Information and Communications Technology for Language Teachers (ICT4LT), Slough, Thames Valley University.

4. Renaud, J. Davies, (2011). Second-Language Acquisition and the Information Age: How Social Software has Created a New Model of Learning," TESL Canada Journal/Revue TESL du Canada, 28(2). 11-19. 
5. Ramachandran, S. (2004). Integrating New Technologies into Language Teaching: Two Activities for EAP Classroom. TESL Canada Journal/Revue TESL du Canada, 22(1).

6. Means, B. (2000). Accountability in preparing teachers to use technology. In Council of Chief State School Officers, State Educational Technology Conference Papers. Washington, DC: Council of Chief State School Officers.

7. Shanker, M., \& Michael, Y. Hu. (2008). Improving Teaching Effectiveness Using Distance. Education Tools, 102-120.

8. Wells, G. (2008). Using the tool-kit of discourse in the activity of learning and teaching. Mind, Culture and Activity, 3(2), 74-101.

9. Michael Dezuanni, (2010). Remixing Media Literacy Education: Students 'Writing' with New Media Technologies.

10. Hartoyo (2008). Individual Differences in Computer-Assisted Language Learning. Semarang: Pelita Insani Semarang.

\section{Список литературы:}

1. Bajcsy R. Technology and learning. In Visions 2020: Transforming education and training through advanced technologies. Washington, DC: U.S. Department of Commerce. 2009.

2. Bennett D., Culp K. M., Honey M., Tally B., Spielvogel B. It all depends: Strategies for designing technologies for educational change. Paper presented at the International Conference on Learning Technology, Philadelphia, PA. 2008.

3. Davies G. Introduction to multimedia CALL. Module 2.2 in Davies G. (ed.) Information and Communications Technology for Language Teachers (ICT4LT), Slough, Thames Valley University. 2011.

4. Renaud J. Davies. Second-Language Acquisition and the Information Age: How Social Software has Created a New Model of Learning // TESL Canada Journal/Revue TESL du Canada, 2011. V. 28. №2. P. 11-19.

5. Ramachandran S. Integrating New Technologies into Language Teaching: Two Activities for EAP Classroom // TESL Canada Journal/Revue TESL du Canada. 2004. V. 22. (1).

6. Means, B. (2000). Accountability in preparing teachers to use technology. In Council of Chief State School Officers, State Educational Technology Conference Papers. Washington, DC: Council of Chief State School Officers.

7. Shanker M., Michael Y. Hu. Improving Teaching Effectiveness Using Distance // Education Tools. 2008. P. 102-120.

8. Wells, G. Using the tool-kit of discourse in the activity of learning and teaching // Mind, Culture and Activity. 2008. V. 3. №2, P. 74-101.

9. Michael DezuanniRemixing Media Literacy Education: Students 'Writing' with New Media Technologies. 2010. 
10. Hartoyo Individual Differences in Computer-Assisted Language Learning. Semarang: Pelita Insani Semarang. 2008.

Работа поступила

в редакичию 15.02.2019 2.
Принята к публикациии

19.02.2019 2.

Cite as (APA):

Sultanova, D., \& Maksudova, D. (2019). Technology-enhanced English language learning and teaching. Bulletin of Science and Practice, 5(3), 465-471. https://doi.org/10.33619/2414$2948 / 40 / 62$.

Ссылка для цчитирования:

Sultanova D., Maksudova D. Technology-enhanced English language learning and teaching // Бюллетень науки и практики. 2019. Т. 5. №3. С. 465-471. https://doi.org/10.33619/2414$2948 / 40 / 62$. 